\title{
THE HAIL FALLS AT THE MOLDAVIA LEVEL AND THE IMPORTANCE OF THE HAIL SUPPRESSION UNIT „MOLDOVA 1" IAȘI
}

\begin{abstract}
Axinte Aurel-Dănuț ${ }^{1,2}$
Key-words: convective clouds, western air-mass movements, hail falls, hail suppression

Abstract. Moldavia, by its location at the contact between temperate-continental climate and that with excessive influences, is characterized by extreme weather events. Such weather's manifestations during of warm period of the year drive at generate of storms, which allow the hail's formation. Based on this study, for the studied area, of importance is the western air mass movements $(47.1 \%)$, followed by those from northwestern $(13.4 \%)$. Also, very important are the south air-mass movements $(10.8 \%)$, all of these in the cyclonic pattern. So, the higher dimensions of the hail (15 to $30 \mathrm{~mm}$ in diameter) were recorded on western or northwestern air-mass movements. Also, in these types of air-mass movements can be distinguished the higher speed of the convective clouds, speeds what can reach even 60 to $80 \mathrm{~km} / \mathrm{h}$ especially at the contact areas between mountains and low lands from surroundings. At the regional level, regarding suppress hail falls, is operative Hail Suppress Unit „Moldova 1" Iasi. This program has proven its efficiency for the protected area of Cotnari (Iasi County), respectively, that of Husi (Vaslui County). Therefore, for Cotnari Protected Area as a result of the hail falls from June $23^{\text {rd }}, 2017$, the active operations into the atmosphere have proven themselves efficiency. As a result, after a few minutes from the cloud's entrance into the active intervention area, the seeding of the convective cells with the antihail rockets' aid, the dimensions of the hail have descended very much in the high reflectivity area of the convective cells. In the future, it's desired to spread this program at the regional and national level and continuing of the researchers in this field to proves the utility of this program and, eventually, enacting other hail suppress technologies, such aviation or ground-based seeding methods. The last process is ideal for rain' augmentation from orographic clouds.
\end{abstract}

\footnotetext{
${ }^{1}$ Hail Suppression Unit „Moldova 1” Iași axinte_dan@yahoo.com

${ }^{2}$ University 'Alexandru Ioan Cuza' of Iași
} 


\section{Introduction}

The geographical position of Moldavia at the European level is one interesting because she is placed at the 'winds crossroad,' away from the central areas of the main baric centers (Bordei-Ion E., 1983). This is characterized through a wide variety of weather patterns during all the year.

In this paper, it wishes a study of the meteorological phenomena characteristic of the convective processes. Between these phenomena, a major role is represented by hail' falls. It noticed that the most favorable intervals with hail's occurrence has been included between 12:00 to 14:00, but also between 15:00 to 17:00, followed by that between 18:00 to 20:00.

The hails are one of the hydrometeors who make much damages to the society, these can reach a few million euro worth (Kunz and Puskeiler, 2010). These can be materialized through spoiled of buildings, cars, compromising the agricultural and vineyard sector, etc (Hohl et al., 2002; Burcea et al., 2016).

To suppress or diminish the damages made by the hail' falls at Moldavia's level, is operative the Hail Suppression Unit „MOLDOVA 1" IAȘI. This one coordinates two Hail Suppression Groups: one at Cotnari (Iași County) and another one at Hussi (Vaslui County). Through the two groups of hail suppression, at the 2019's beginner, were protected 13,000 sq km (5019.3 sq mi), mainly the vineyard areas (Istrate et al., 2019).

Besides of the clouds' seeding methods with the anti-hail's rockets (RAG-96 and RAG-96s (http://www.elmecph.ro/produse.html) it's fallowed approached of complementary technologies such of the ground-based and aerial clouds seeding who will play a major role to augmentation the precipitations.

\section{Data and methods used}

The present study has been made through analyzing and the statistical interpretation of the hail phenomenon at the region's level for 2017 and 2018's convective period. All the data provided by meteorological RADAR (Bârnova DIS), from Meteorological National Administration (MNA, Burcea, et al., 2010). This one is in S-band with a range action estimated at $230 \mathrm{~km}(142.92 \mathrm{mi})$.

From these sources were analyzed values that referred at all of the convective cells which passed the protected areas and its surroundings. In doing so has taken into account data relating to value (offered by RADAR from 6 to 6 minutes), name of the convective cell, reflectivity, direction and speed and the hail's dimension in the maximal reflectivity of the cells. The way to define the cells that can generate hailstorms has been according to $45 \mathrm{dBZ}$ contour. For this study, we took into account all the convective cells which were able to produce hail on $100 \mathrm{~km}(62.14$ $m i$ ) distance from Hail Suppression Groups of Cotnari and Huși. Subsequently, all of these data were statistically interpreted. 


\section{Result and discussions}

During the warm season of the 2017's year at Moldavia level, the most typical situations in which have generated extend westerly air-mass movements represented convective cells. All of these have cumulated about $47.1 \%$, followed by the northwestern with $13.4 \%$ (fig. 1). Those directions have generated the most violent storms; this while the cold air by maritime-polar origins replaced the warm pre-existent air-mass. In last time, because of global warming, the frequency and intensity of the extreme weather events have increased (IPCC, 2014; Kovats et al., 2014).

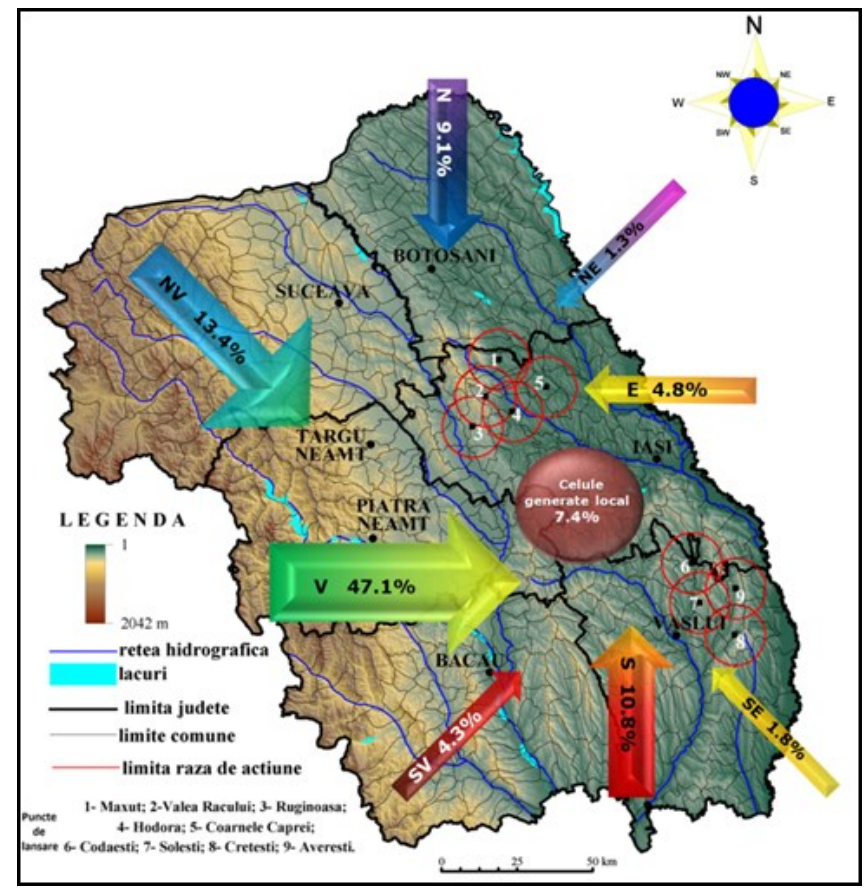

Fig. 1 - Weigh of the convective cells' movement in Moldavia - the convective period of 2017

Besides of the dynamic factor, the topography characteristics are significant in generating the convections over the northern and central part of Moldavia. Linked by this aspect, slightly arched shape of the Wooded and the Eastern Carpathian give some particularities to the atmospherically dynamic at regionally scale. As a result, the maritime-polar air-mass by oceanic origins is integrated into a northwesterly to southeasterly movement, all of these situations because of the „Coandă effect” who takes place at the local level (Bordei-Ion N., 1988). 
The air-mass once replaced on this direction have trends to take speeds higher driving to a sudden thermodynamics' characteristic in the lower and medium troposphere. This context - on the northwesterly air-mass movements (13.4\%) - is the most favorable to the development of big storms (fig. 2).

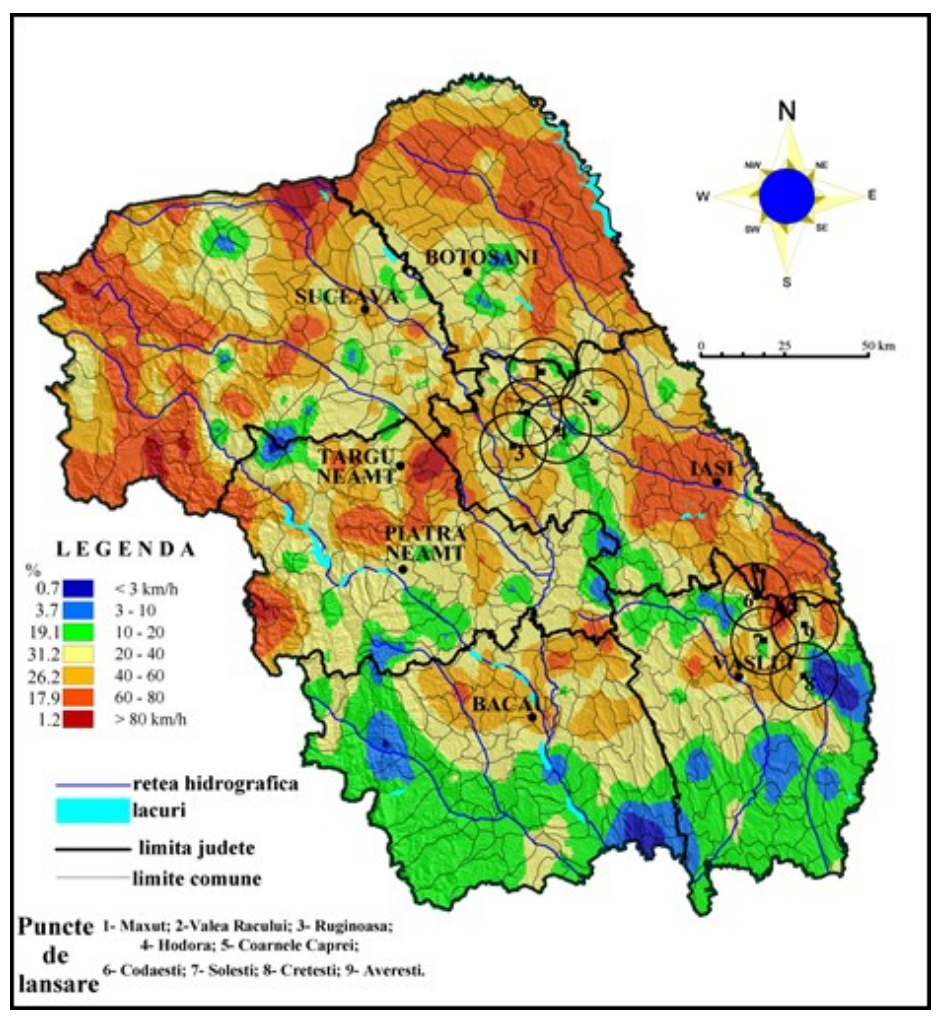

Fig. 2 - The territorial distribution of the convective clouds' movement in Moldavia - the convective period of 2017

For southerly air-masses movements (10.8\%) and from south-westerly (4.3\%) take place warm and moist air-mass movements in the cyclonic pattern (Ilie et al., 2016). In these scenarios is generated that type of convective linear multi-cell systems. According to local characteristics, by cells' stimulating of the Carpathian Mountains range can be severe weather events.

In the end, low values until 5 to $10 \%$ can be associated with the easterly airmass movements. All of those are associated by many times with the retrogressive cyclones (Apostol, 2008). These meet high-pressure areas placed over eastern parts 
of Europe. Moreover, the warm waters of the western and northwestern parts of the Black Sea help at moisture surplus regenerated these depressions.

In the eastern air-mass movements' case on behalf of the convective processes, and not only, can be recorded substantial amounts of rainfall. Besides, the Mediterranean low-depression represents an important weigh into the total amounts of precipitation recorded at Moldavia's level.

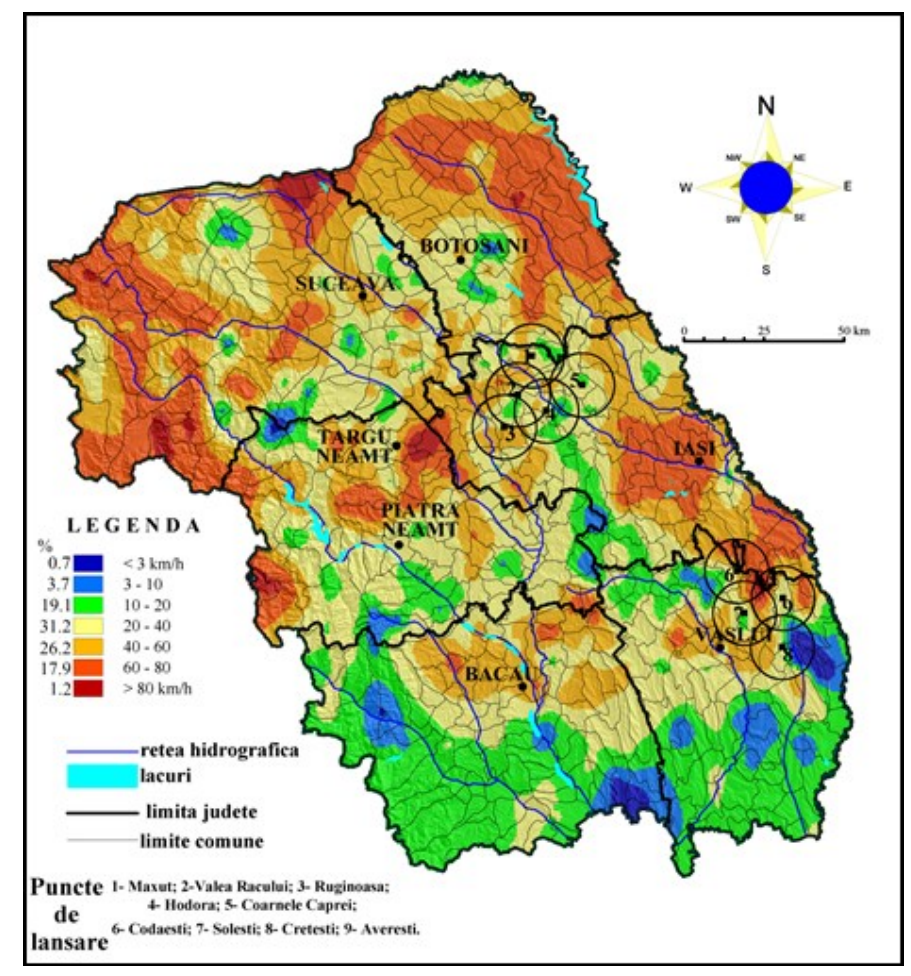

Fig. 2 - The territorial distribution of the convective clouds' movement in Moldavia - the convective period of 2017

According to attached product based by data obtained from RADAR WSR98D - Bârnova can distinguish the movement speeds of the convective clouds systems in Moldavia. So, at the record areas established between the Carpathian Mountains range and lower areas from the Siret's Valley can be noticed high speeds of the convective clouds. On this case, speeds between 40 to $60 \mathrm{~km} / \mathrm{h}$ (fig.2) are given, mainly, by westerly movements. In doing so, the mountains areas represent the local factors which can influence the climate's trend at the local level (Binder and Schär, 1996). 
Another essential thing noticed on this map it's represented by convective clouds systems which approached the northern half of Moldavia. These show speed even higher, until 60 to $80 \mathrm{~km} / \mathrm{h}$. In that case, the main vector which drives to the convective structures' movement represented by northwestern direction. In this situation, we speak about the cold air-masses from North-Western part of Europe. All of these linked by „Coandă effect” about we spoke above.

The channeling of the air-masses over Moldavia, especially over her northern and central part, is associated with high speed of the cloud systems. In doing so can be distinguished in the north part of the studied area, a section where the clouds' speed exceeds $80 \mathrm{~km} / \mathrm{h}$. Besides, another high speed of clouds can be found alongside the Prut River. In the lee, depression areas, the movement speeds are low, on average, under $10 \mathrm{~km} / \mathrm{h}(6.2 \mathrm{mph})$.

In studying and suppression of hail falls, a crucial way is to know that section in the cloud of the storm where the hail has the most probability to form. Here we can expect the significant dimension of the hail. This section is placed where the cloud shows the highest reflectivity (dBZ).

Based on the archive associated with the active intervention into the atmosphere in 2017 we can distinguish alternating between areas where the dimension of hail in the maximal reflective regions was very high (values which exceed $3.71 \mathrm{~cm}$ or $1.46 \mathrm{in}$ ) with those where these values were shallow (under 1.27 cm or .5 in).

Because that year was one representative for convective cells that formed predominantly upon westerly and northwesterly movement with warm and moist air-mass replacements, in these convective clouds has developed hail which had impressive dimension over $6 \mathrm{~cm}(2.36 \mathrm{in})$ in diameter. All of these situations were associated with the northwestern, subsequently, with a quick pass toward an anticyclonic regime (Ilie et al., 2016).

Unlike the previous year, the 2018 year was characterized by a high rate of cloudiness. That, as a result of the fact that the clouds have re-generated from the Black Sea. Despite this fact, the hail's dimension was smaller than on the previous year. In cases when low-pressures areas are associated with a retrogressive trend (Apostol, 2008), the highest dimension of the hail to be focused mainly on the eastern and southeastern part of the researched area.

In case of the north-westerly or westerly air-mass advection by many times are available severe weather conditions. On this case, of southeasterly or easterly airmass movements, the precipitations are more contiguous, with a more uniform spread (Bordei-Ion Ecaterina, 1983).

If the year of 2017 can be characterized by hail's dimension on average between 1.27 to $1.91 \mathrm{~cm}$ with over 50\%, the 2018 year's case has prevailed these under $1.27 \mathrm{~cm}(.5 \mathrm{in})$ in diameter. So, in case of westerly or northwesterly 
movements, the hail shows values bigger. In contrast with that in the case of easterly or southeasterly movements, the hail's dimension is lower.

The outgoing of these two years was averaged to see from where will occur a higher risk of hailstorms (fig. 3). As a result, the most exposed areas at hailstorms are figured of main rivers (Moldova, Bistrița, Jijia), but also the Central Moldavian Plateau.

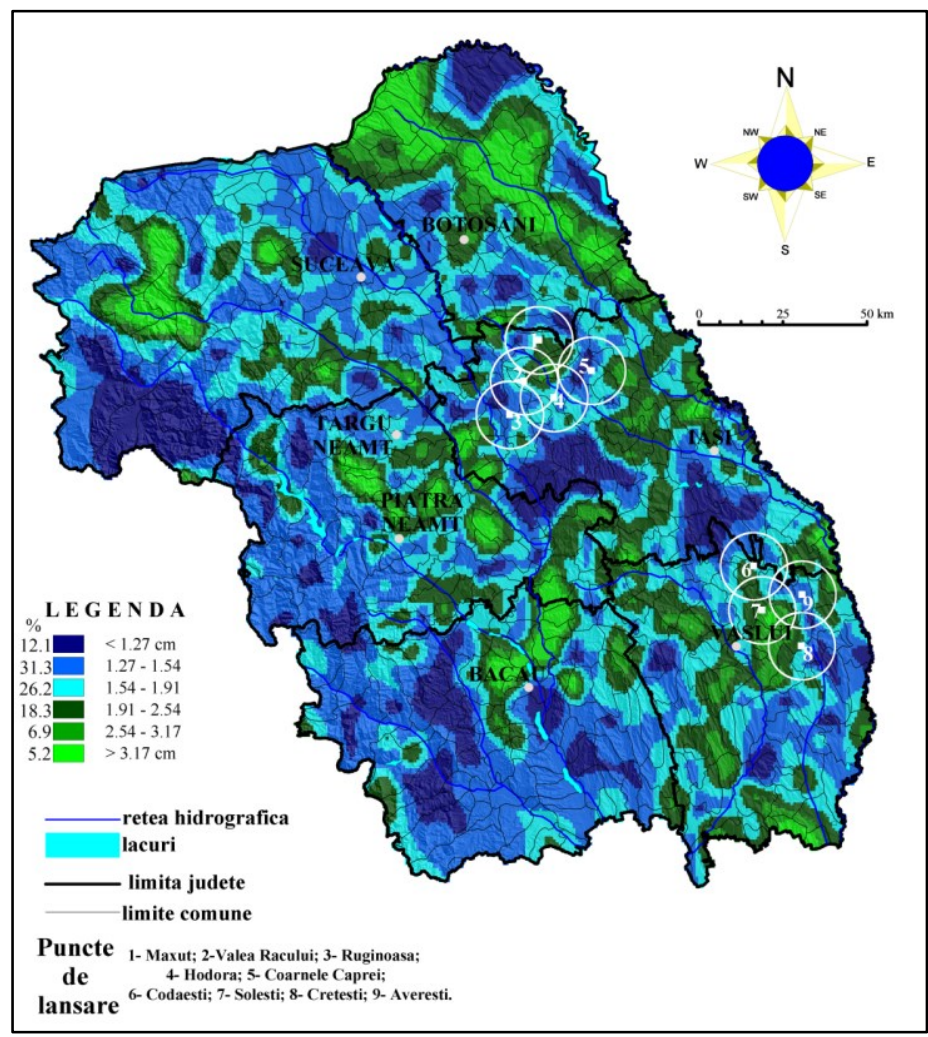

Fig. 3 - The territorial distributions of the hail dimension on maximal reflectivity areas over Moldavia - an average over convective periods of 2017 and 2018

Of importance for hail, suppression is the way of terrain's knowledge, too (Istrate et al., 2019). The vegetation, mainly which represented by fruit-trees and forest areas, figure out a second active surface. This situation plays a significant role to generate the convective clouds.

Based on hail dimensions' mediation in those two years, with the highlighted those who exceed $1.91 \mathrm{~cm}$ in diameter on the maximum reflectivity and the land's 
use (CORINE Land Cover - CLC) had been obtained areas where the hail occurrence rate is the higher (fig. 4). The albedo of all of low areas can generate a thermal energy surplus, necessarily of the convective processes (Marsham et al. 2008).

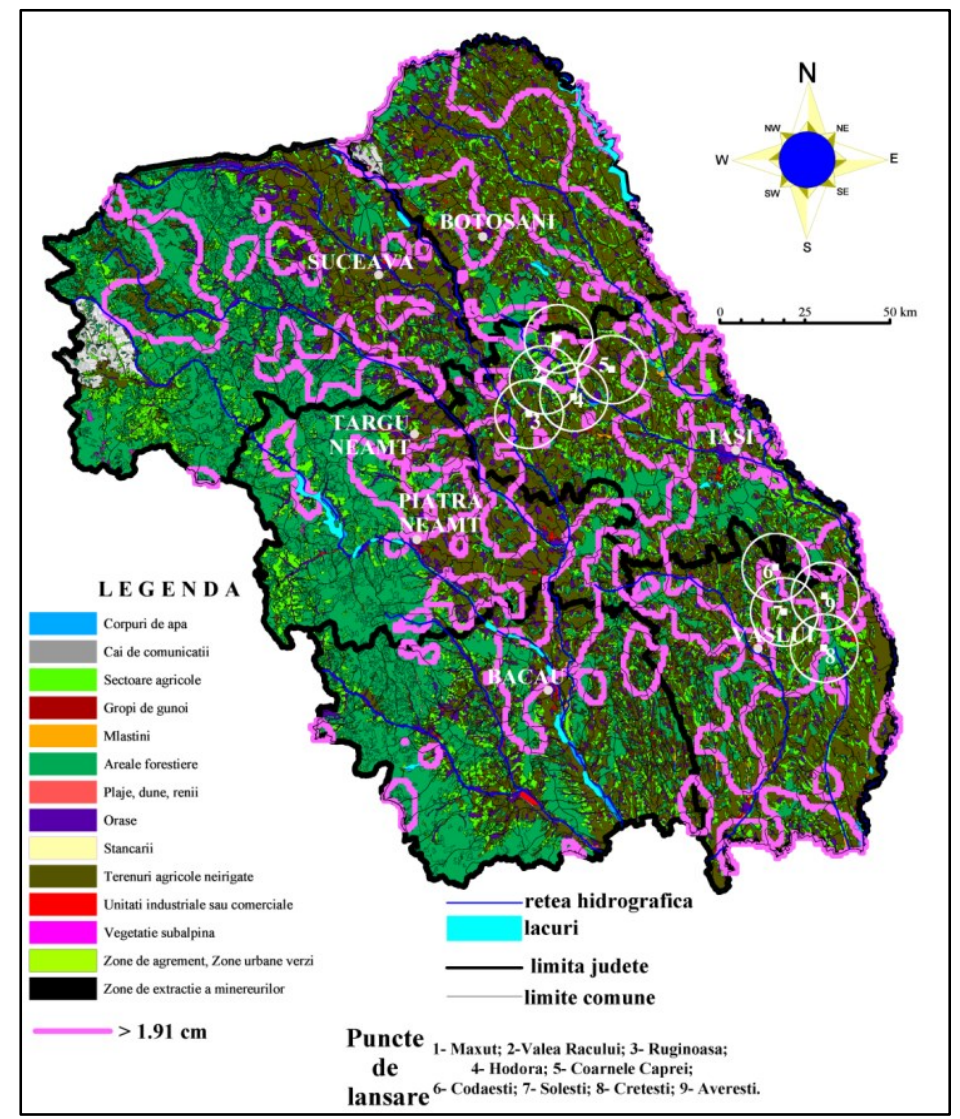

Fig. 4 - The spatial distribution of hail in the max. reflectivity areas with over $1.91 \mathrm{~cm}$ over Moldavia - an average upon 2017 - 2018 years in accordance with the land's use

In the areas placed alongside the main rivers flow (Moldova, Bistrița, Jijia, Prut) the hail falls can represent a significant danger. The lakes represent a surplus of energy at the local scale, necessary at convective processes. Thus, the water surplus integrated with the ascendant fluxes represents a good source for CAPE increase, while the CIN decreases. 
At more detailed look were taken into account two significant episodes when the hailstorms represented a direct risk for Cotnari and Huși protected areas.

For Cotnari Protected Area, the worst situations are figured out by westerly and northwesterly air-masses movements.Thus, the day of June, $23^{\text {rd }}, 2017$ was characterized by a violent warm air-mass replacement with another cold, by maritime-polar origins $(\mathrm{mP})$. On this context with are inserted the high atmospherically moisture, the vegetation shown the maximum itself phase and a long period with rains, the manifestation rate of the instability was at maximum level.

In this situation the diameter of hail reached over $10 \mathrm{~cm}$ recorded at $20-25 \mathrm{~km}$ west side of the protected area (fig.5). On the frame of the protected area, the X1 convective cell showed hail's dimensions over $5 \mathrm{~cm}$. Once the cell got influenced, it can distinguish a decrease of the hail's sizes.

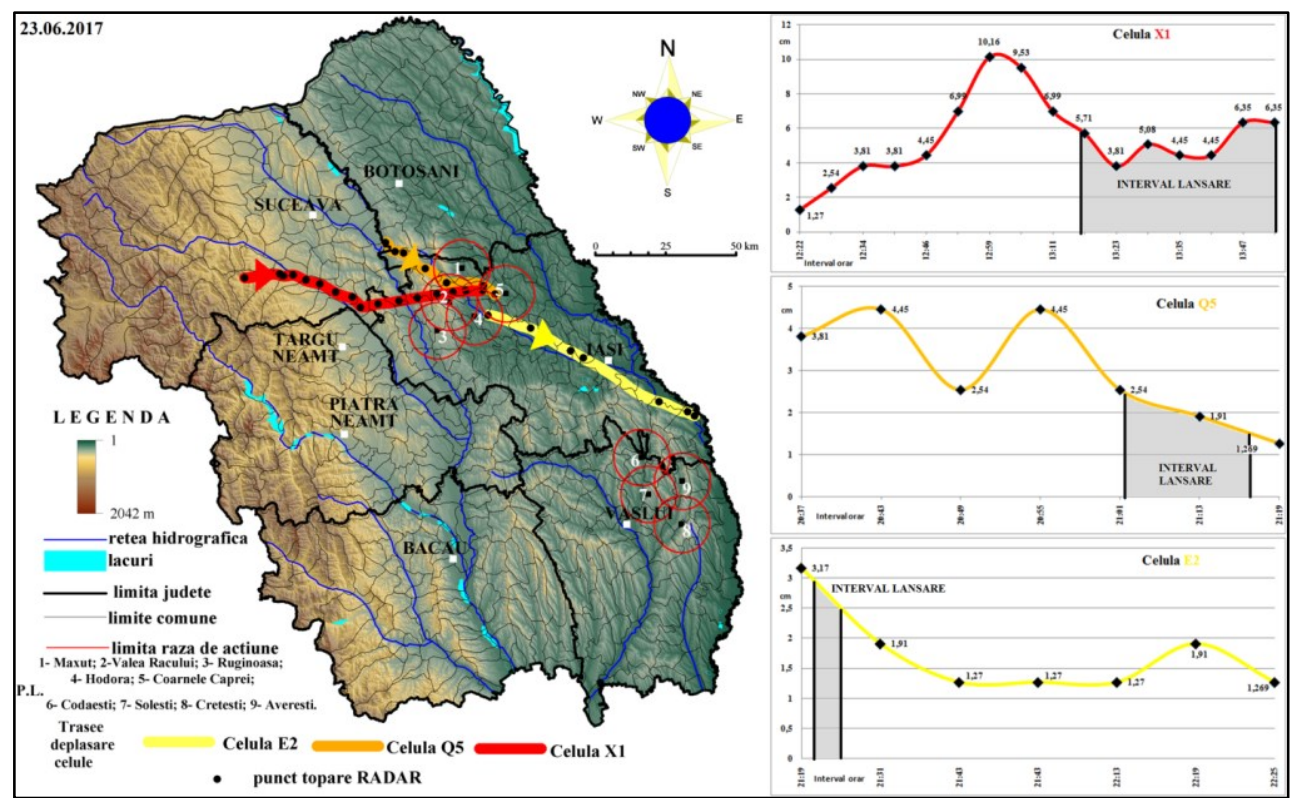

Fig. 5 - The cells' evolution influenced into the protected area of Hail Suppression Unit „Moldova 1" Iasi on June $23^{\text {rd }} 2017$

Also, the next cells which passed the Protected Area of Cotnari - Q5 and E2 have shown a noticeable trend of decrease the dimension of hail.

Another case with active convective cells' influence is represented of that from June $28^{\text {th }} 2018$, but in the Protected Area of Huși. Here, interest is shown by these movements from eastern and south-easterly. That day was one when such 
atmospherical circulations had represented the primary vector of the convective cells.

In contrast with the situation shown previously, the hail's dimension was smaller (fig.6). In this case, the movement which involves a maritime polar airmass replace the warm and moister air mass very quickly.

For this time can be noticed a long period with launching interdictions, when the cell L6 has passed the Protected Area of Huși. In all of that time, the hail's dimension continued to increase. Once lifted the launching interdiction and started the influences against the cell has driven at a decrease of the hail's sizes.

Such situations had shown highlighted the most favorable period with hail occurrence. These periods are the most frequency during noon and afternoon hours.

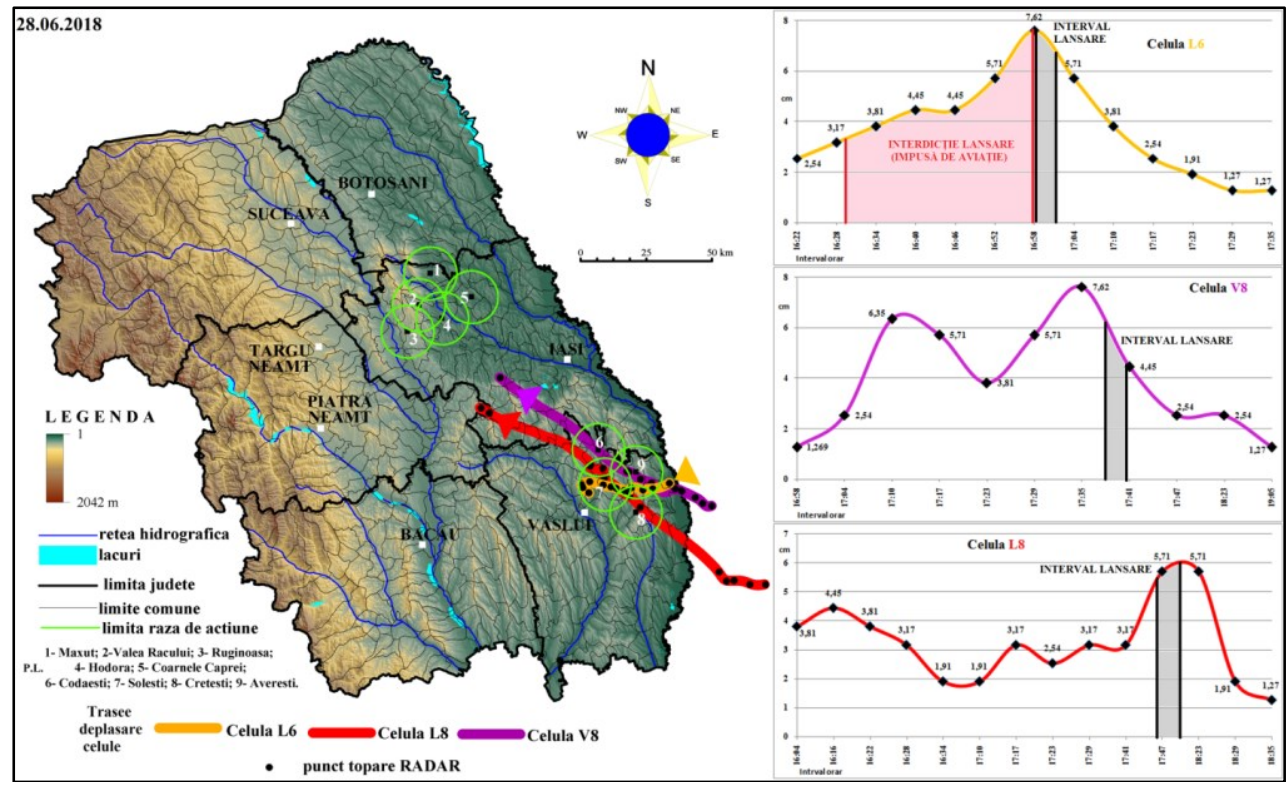

Fig. 6 - The cells' evolution influenced into the protected area of Hail Suppression Unit „Moldova 1" Iasi on June, $28^{\text {th }}, 2018$

In the future, it wishes that this to be spread at regionally and nationally scale. Besides that, it wishes to make more studies about that and to adopt complementary technologies through to combat the hail falls. For these facts will be necessary detailed studies which to figure out the atmospherically dynamic (Warburton, 1971; Fisher, 2018). 


\section{Conclusions}

The most favorable patterns of the hail's occurrence are on westerly and northwesterly air-mass movements (47.7\% in 2017). Also, such movements of airmasses develop a higher dimension of hail. In the opposite side, the eastern represent the lowest height, below 3 to $5 \%$ (2017).

In this study were taken into account based upon the RADAR archive from Bârnova (Iași County) for 2017 and 2018 years. Also, for these years, we wished to expose a particular situation for each year.

As a result, associated with the year of 2017, of interest were the westerly and northwesterly air-mass movements which generated high dimensions of hail. In the 2018 's case, with easterly and southeasterly air-mass flows, the sizes of hail were smaller.

\section{References:}

1. Apostol L., (2008) - The mediterranean cyclones - the role in ensuring water resources and their potential of climatic risk, in the east of Romania. Present Environmental and Sustainable Development, Iași, Vol. 2, 2008, p. 143-163.

2. Apostol L., Sfîcă L. (2013) - Thermal differenciations induced by the Carpathian Mountains on the Romanian territory, Carp J Earth Environ Sci 8(2), p.215-221.

3. Bordei-Ion, Ecaterina (1983) - Rolul lanţului alpino-carpatic în evoluţia ciclonilor mediteraneeni, Edit. Academiei, Bucureşti.

4. Bordei-Ion N. (1988) Fenomene meteoclimatice induse de configurația Carpaților în Câmpia Română, Ed. Academiei Române, București, România, p.224.

5. Burcea S., Cică R., Bojariu R. (2016) - Hail Climatology and Trends in Romania: 19612014, American Meteorological Society, Vol. 144, p. 4289-4299, doi: https://doi.org/10.1175/MWR-D-16-0126.1.

6. Didovets I., Krysanov V., Bürger G., Snizhko S., Balabukh V., Bronstert A. (2019) Climate change impact on regional floods in the Carpathian region. Journal of Hydrology: Regional Studies, Vol. 22, April 2019, 100590, p.- în curs de publicare (octombrie 2019) doi: https://doi.org/10.1016/j.ejrh.2019.01.002.

7. Fisher J. M., Lytle M. L., Kunkel M. L., Blestrud D. R., Dawson N. W., Parkinson S. K., Edwards R., Benner S. G. (2018) - Assessment of ground-based and aerial cloud seeding using trace chemistry. Hindawi, Advances in Meteorology, Volume 2018, Article ID 7293987, 15 pages Doi: https://doi.org/10.1155/2018/7293987.

8. Hohl R., Schiesser H.H., Aller D. (2002) - Hailfall: The relationship between radar-derived hail kinetic energy and hail damage to buildings. Atmos. Res., 63, p.177-207, doi:https://doi.org/10.1016/S0169-8095(02)00059-5.

9. Istrate V., Ursu A., Dobri R. V., Axinte A. D., Stoica D. (2019) - Hail suppression system in Romania and its relation with land cover. Conference: 19th SGEM International Multidisciplinary Scientific GeoConference EXPO Proceedings, Albena, Bulgaria, Vol. 2, p. 1071-1079 doi: DOI: 10.5593/sgem2019/2.2. 
10. Kunz M., Puskeiler M. (2010) - High-resolution assessment of the hail hazard over complex terrain from radar and insurance data. Meteor. Z., 19, p. 427 -439, doi:https://doi.org/10.1127/0941-2948/2010/0452.

11. Marsham J.H., Parker D.J., Grams C.M., Johnson B. T., Grey W. M.F., Ross A.N. (2008) - Observations of mesoscale and boundary-layer scale circulations affecting dust transport and uplift over the Sahara. Atmos. Chem. Phys., 8, p. 6979-6993.

12. Warburton J. (1971) - Physical evidence of transport of cloud-seeding materials into areas outside primary targets," in Proceedings of International Conference on Weather Modification, pp. 185-190, Canberra, Australia.

13. *** http://www.elmecph.ro/produse.html

(C) 2020 by the authors. Licensee UAIC, Iasi, Romania. This article is an open access article distributed under the terms and conditions of the Creative Commons Attribution (CC BY-NC-ND) license (https:// creativecommons.org/licenses/by-nc-nd/4.0). 